\title{
Research on Colleges and Universities Sports Teaching Based on the Concept of Health Quotient
}

\author{
Jian-qiang GUO ${ }^{1,{ }^{*}}$, Wen-jie ZHU² and Qin-er XU ${ }^{1}$ \\ ${ }^{1}$ Changzhou University sports institute \\ ${ }^{2}$ Suzhou Art and Design Technology Institute, Jiangsu Suzhou, China \\ *jqguo5986@163.com
}

Keywords: Health quotient concept, College physical education, Quality education, Education idea.

\begin{abstract}
In recent years, college students' physical and mental quality are decreasing year by year. The lack of students' health quotient concept has become an important factor to affect students' all-round development. But the lack of physical education teachers' health quotient in colleges is largely influenced by the educational function of the sports curriculum, which is not conducive to the sustainable development of college physical education teaching. Based on analyzing the definition of health quotient concept and the important meaning to put it into college sports teaching, Provide a reference for the health development of college PE education.
\end{abstract}

\section{Introduction}

With China's higher education from elite education to mass education, college student source structure is becoming increasingly complicated and especially the one child oriented $90 \mathrm{~s}$ students become the main force of the contemporary college students. More and more problems of college students in physical and psychological aspects have appeared. Many phenomenons that the students' IQ and EQ is not coordinated have been found, such as resilience difference, emotional fragility and hot temper. It should be taken seriously by the educational worker. Because in the social competition increasingly fierce, people only have high IQ, EQ is not enough; he also needs to have a high HQ and a healthy body. Therefore, the practice of health quotient application and guidance in college physical education teaching can help students to establish a correct concept of sports learning, develop the consciousness of lifelong physical education and better meet the realistic demand of college sports teaching objectives.

\section{The Definition and Connotation of Health Quotient}

Health quotient (HQ) is a index conception that is based on the modern science citation and health knowledge and used for a comprehensive evaluation of the people health. From the microscopic point of view, health quotient is mainly a person's soul quotient, body quotient, popularity quotient and sex quotient. It is a reflection of a person's health level and health attitude and an important index to evaluate the health of the people. From a macro perspective, health quotient can also means that a person should be or already have health awareness, health knowledge and health skills and all three are related closely. Therefore, with the health concept proposed, people are accustomed to putting the IQ, EQ together as an important standard to judge a person's basic quality. Each person has be some difference in health quotient level. 
But different with the IQ and EQ, health quotient mainly depends on a person's acquired factors. It can be attained through personal participation in sports and also improved by knowled ge learning and emotional intelligence development.

In short, HQ pays more attention to the best state for a person in physiological, psychological and social health, emphasizing the people to improve their health through their physical exercise and sports awareness. Based on the HQ concept, sports teaching in colleges is a kind of brand-new teaching idea, can realize the innovation and development of college sports teaching ideas and methods and has very important guiding significance for promoting the development of physical and mental quality of college students.

\section{The Important Significance of Introducing Health Quotient Concept into College Physical Education Teaching}

For college students, physical and mental health is not only to guarantee the basic conditions for their successful completion of their studies. It has become an important precondition for getting to society to serve the socialist modernization in the future. Health quotient concept should be put into the university sports teaching, make students have health knowledge and perfect sports consciousness, develop good exercise habits and health behavior and gradually establish "health first", "lifelong sports" consciousness, so that the students benefit from it the whole life.

\section{An Important Measure to Adapt to the Reform of College Sports Teaching}

Under the background of quality education, with the implementation of college sports new curriculum standard, the key of university sports teaching has achieved a positive change from competitive sports to the health sports. Because of the demand for talent in modern society, not only needs high level of intelligence and emotion attitude, also needs healthy body and strong interpersonal skills. Therefore the current PE teaching should pay more attention to the cultivation of students' health consciousness and life-long sports consciousness and enhance the enthusiasm of students to participate in sports. Physical education health concept can not only help students gain a more healthy knowled ge and skills and improve the health level of intelligence of students, but also can guide them to choose sport and exercise projects that are suitable to them and develop good psychological quality and physical exercise habit. This requires the teachers to develop HQ quality of students in teaching practice purposefully, so that we can better meet the needs of the reform of college sports teaching reality.

\section{Help Students to Develop Life-long Sports Concept}

Physical and mental health is the foundation of one's to maintain physique and prolong vitality.

It is the source of personal health, happiness, well-being even success and one of the main objectives of physical education in colleges at present. College sports teaching reform, based on the idea of health quotient, requires teachers and students to establish "position guiding health first" thought, get out of the traditional misunderstanding that sports teaching should lay stress on the students' athletic quality education as soon as possible, treat the students' interest in sports, exercise habits and health awareness training as the focus of teaching, enhance the students understanding of health sports, grow the students' sports skills, at the same time, help students be fully aware of the sports curriculum value, gradually develop good habits and healthy sports concept, strengthen students' ability of lifelong sports ability and 
lifelong sports consciousness, make sports become students an important part even later in life and realize their own physical quality to improve continuously.

\section{Improve the Evaluation System of College Physical Education Teaching}

College physical education, under the traditional mode teaching evaluation, mainly adopts a unified, standardized index and focuses on students' evaluation of sports skills. It is a consequential evaluation and its main teaching evaluation is relatively single. But with the introduction of the health quotient concept in college physical education, in addition to evaluate the students' sports skills, it is required to increase to evaluate students interested in sports, sports attitude, sports moral process and make effective unification college sports teaching quantitative evaluation and qualitative evaluation come true, so that we are able to take different teaching strategies and evaluation methods for different levels of students, make every student to establish a correct attitude towards sports curriculum, establish the scientific learning goals and promote the internalization and development of contemporary college students' good sports habits and physical quality.

\section{Contribute to the Development of Conte mporary College Students to Achieve a Better Life}

With the continuous development of college physical education theory, in order to better meet the needs of the development of students' life, sports teaching in colleges begins to gradually increase the proportion of health education, life education and lifelong education sports concept. Introducing the health quotient concept in college physical education can make students form correct sports and fitness philosophy before entering the society, have a positive impact on the students' development into the community sports and lay good foundation of the body. It will be very good for the contemporary students to realize their ideals and aspirations. Also it can be more appropriate to the requirements of society for contemporary college students.

\section{Conclusions}

In short, the college sports curriculum reform and teaching research, based on health quotient concept, is the inevitable choice to improve the teaching quality of college physical education under the background of quality education. It helps to enhance students' interest to PE course, develop good exercise habits and promote the coordinated development of contemporary college students' physical and mental quality.

\section{Acknowledgme nts}

This paper for the national social science fund project "the study of urban and rural public sports service equalization demonstration area in the south of jiangsu construction of one of the achievements". Item number: 14BTY105.

\section{References}

[1] Wang JingYing. Improving the "health quotient" is a new subject in College Physical Education Teaching Reform under the new situation [J].Sport, 2009, (03): 13-14. 
[2] Yang LianBo, Jia Jie. Relying on the "health quotient" new ideas, researches and explorations on physical education system in colleges have been improved. [J].Science and Technology Review, 2010, (09):23-24.

[3] Tong MeiMei. Using the teaching of college physical education to promote modern college students mental health [J].Sports World (Academic Edition), 2011, (01):16-19.

[4] Wang XiaoMei, Li JunHan. A brief analysis of college physical education teaching reform under health education concept [J]. Journal of Southwestern Normal University (NATURAL SCIENCE EDITION), 2008, (04):47-49.

[5] Wang JingYing. Study on the significance and measures to foster the students "Health Quotient" in PE Teaching in Colleges [J]. Journal of Jilin Institute of Physical Education, 2010, (06):67-69. 